\title{
Ischaemia reperfusion injury: mechanisms of progression to chronic graft dysfunction
}

\author{
Gerhard R. Situmorang ${ }^{1,2} \cdot$ Neil S. Sheerin ${ }^{1}$ (b) \\ Received: 18 December 2017 / Revised: 18 February 2018 / Accepted: 2 March 2018 / Published online: 30 March 2018 \\ (C) The Author(s) 2018
}

\begin{abstract}
The increasing use of extended criteria organs to meet the demand for kidney transplantation raises an important question of how the severity of early ischaemic injury influences long-term outcomes. Significant acute ischaemic kidney injury is associated with delayed graft function, increased immune-associated events and, ultimately, earlier deterioration of graft function. A comprehensive understanding of immediate molecular events that ensue post-ischaemia and their potential long-term consequences are key to the discovery of novel therapeutic targets. Acute ischaemic injury primarily affects tubular structure and function. Depending on the severity and persistence of the insult, this may resolve completely, leading to restoration of normal function, or be sustained, resulting in persistent renal impairment and progressive functional loss. Long-term effects of acute renal ischaemia are mediated by several mechanisms including hypoxia, HIF-1 activation, endothelial dysfunction leading to vascular rarefaction, sustained pro-inflammatory stimuli involving innate and adaptive immune responses, failure of tubular cells to recover and epigenetic changes. This review describes the biological relevance and interaction of these mechanisms based on currently available evidence.
\end{abstract}

Keywords Kidney transplantation · Acute ischaemic injury · Delayed graft function · Chronic graft dysfunction · HIF-1 · Hypoxia $\cdot$ Endothelial dysfunction

\section{Introduction}

The global burden of chronic kidney disease (CKD) has been steadily increasing over recent years. This has resulted in a continuing rise in the number of kidney transplants performed, but also identifies a major problem for kidney transplant programmes - a shortage of available donors. The increasing use of extended criteria donors and utilisation of ex vivo normothermic perfusion technologies are some of the steps taken to increase the donor pool. However, this will also increase the number of organs with more severe ischaemic injury, potentially increasing the risk of delayed graft function and earlier deterioration in graft function. A comprehensive understanding of molecular events involved in post-ischaemic kidney

Neil S. Sheerin

neil.sheerin@ncl.ac.uk

1 Institute of Cellular Medicine, Newcastle University, Newcastle upon Tyne NE2 4HH, UK

2 Urology Department, Faculty of Medicine Universitas Indonesia Cipto Mangunkusumo Hospital, Jakarta 10430, Indonesia injury and how they may affect the long-term function of the organ is crucial in formulating prevention strategies and to identify novel therapeutic targets. We review the available evidence on the underlying mechanisms involved in the progression of acute kidney injury (AKI) to $\mathrm{CKD}$, focusing on transplantation.

\section{The link between AKI and CKD}

An increasing number of clinical epidemiology studies have reported an association between AKI and the development of CKD $[1,2]$. Despite the well-established epidemiological link between $\mathrm{AKI}$ and $\mathrm{CKD}$, evidence to support a causative relationship between the two clinical entities is still lacking. Transplant patients serve as an ideal cohort to investigate the link between acute ischaemic injury and development of late organ dysfunction. Ischaemic injury in kidney transplantation initially manifests as delayed graft function (DGF), which is associated with prolonged hospitalisation and the need of renal replacement therapy post-transplant. Nevertheless, recovery of organ function is usually achieved in patients with DGF, indicating a degree of resolution of acute ischaemic injury. 
However, several studies have reported that patients with DGF have increased risk of acute rejection and poorer long-term renal function [3]. These findings provide a link between acute ischaemic injury to the kidney and long-term deterioration in graft function, despite relatively "normal" function in the earlier stages. Several mechanisms have been proposed in the development of chronic dysfunction, as illustrated in Fig. 1. It is important to consider these mechanisms not as separate pathophysiologic entities, rather as components of an intricate network with many overlapping, co-existing pathways.

\section{Role of hypoxia and hypoxia-inducible factor (HIF)}

\section{The renal response to hypoxia}

The anatomy of the nephron and renal microcirculation plays a crucial role in understanding the effect of ischaemia on the kidney. In physiological conditions, kidneys receive approximately $20 \%$ of cardiac output. This blood flow is primarily channelled to the cortex with blood flow to the medulla predominantly from the vasa recta, a continuation of efferent arterioles of the juxtamedullary glomeruli. In comparison to other parts of the body, the kidney, particularly the outer medulla, operates at lower oxygen tensions, both during normoxia and hypoxia [4]. This is due to post-glomerular arterio-venous shunting and high oxygen demands [5]. In response to hypoxia, kidney blood flow may alter dramatically, especially to the outer medullary region, reducing oxygen delivery and increasing hypoxic injury in this region.
The capacity of a kidney to withstand an ischaemic injury or to undergo repair after an ischaemic injury is highly dependent upon the available nephron mass, pre-existing glomerulosclerosis and arteriosclerosis [6, 7], features typically associated with increasing donor age. In experimental models of transplantation, older kidneys were more susceptible to ischaemic injury even after a brief ischaemia time [6]. A retrospective analysis of the Australian and New Zealand transplant registry by Wong et al. [8] also suggests a significant interaction between total ischaemic time, donor age and graft function, with higher DGF rates in recipients receiving kidneys from older donors.

The mechanism by which a further reduction in oxygen delivery to the kidney induces AKI has been well established. However, demonstrating the role of hypoxia in progression of kidney injury in the longer-term is more challenging. Several studies have shown an association between chronic tubulointerstitial hypoxia, oxidative stress and chronic inflammation, and that these factors are involved in the progression of CKD [9, 10].

\section{The role of hypoxia inducible factor}

Cellular adaptation to hypoxia is largely regulated by a heterodimeric transcription factor, hypoxia-inducible factor (HIF), which consists of two sub-units; $\alpha$ and $\beta$. Whereas the $\beta$ sub-unit is relatively insensitive to alteration in oxygen levels, the level of the alpha sub-unit (HIF- $\alpha$ ) is highly dependent on cellular oxygen tension $[11,12]$. HIF- $\alpha$ has two major isoforms; HIF- $1 \alpha$, HIF- $2 \alpha$ and one additional minor isoform HIF-3 $\alpha[11,13]$. HIF- $\alpha$ is expressed at a basal level in cells

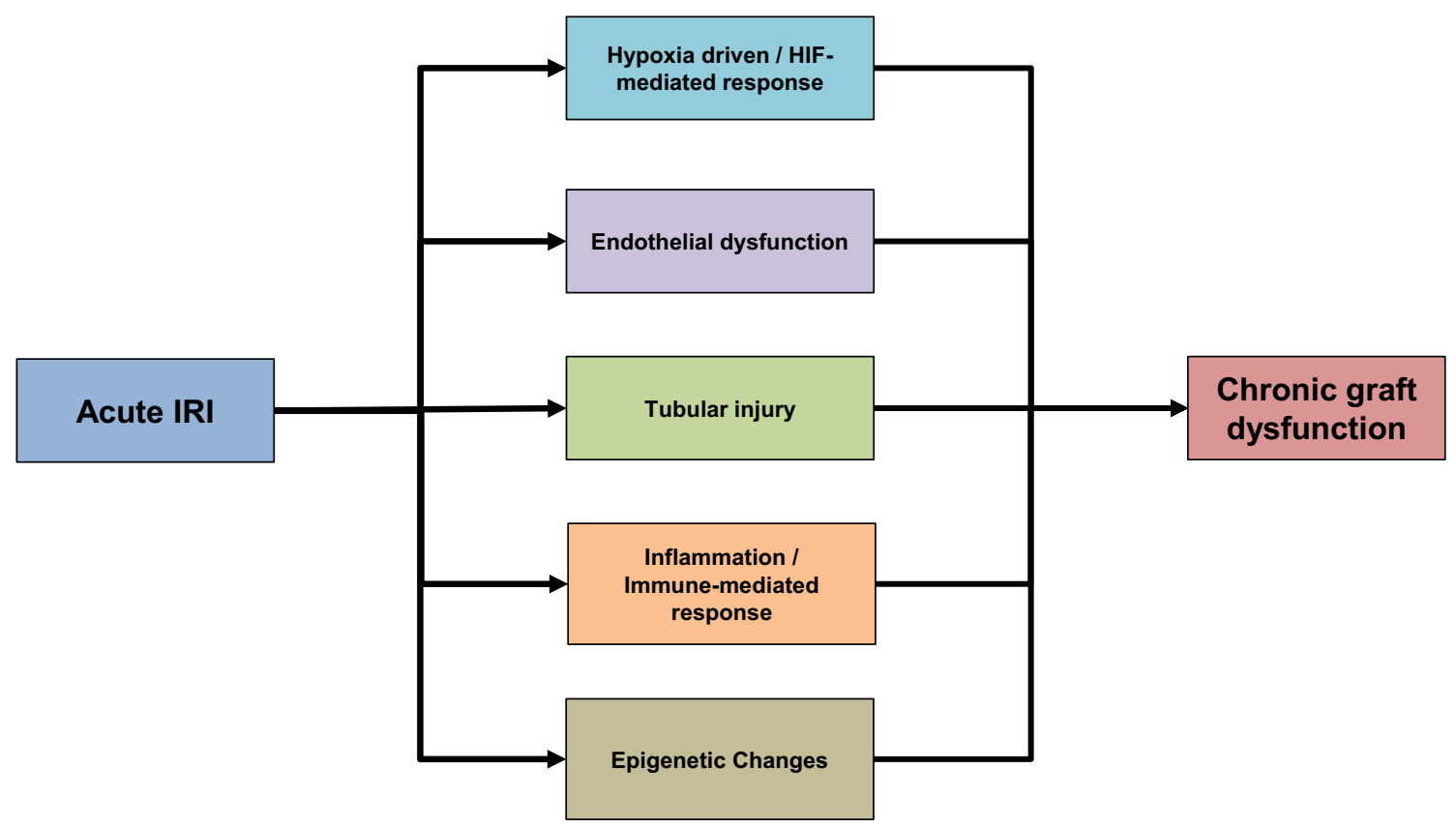

Fig. 1 Mechanisms proposed in the development of chronic graft dysfunction. IRI ischaemia-reperfusion injury 
but in normoxic conditions HIF- $\alpha$ is hydroxylated by HIFprolyl hydroxylase (PHD) leading to ubiquitination and degradation. In order to perform their catalytic function, HIFprolyl hydroxylases require $\mathrm{O}_{2}, \mathrm{Fe}$ and 2-oxoglutarate (an intermediate in the Tri-carboxylic acid cycle) [14]. In normoxic conditions, degradation occurs very rapidly, resulting in very short half-life of HIF- $\alpha$, making it almost undetectable in healthy cells. During hypoxia, HIF-propyl hydroxylase function is reduced, leading to accumulation of HIF- $\alpha$ in the cytoplasm. HIF- $\alpha$ forms a complex with the constitutively expressed HIF- $\beta$, leading to nuclear translocation and binding of the complex to hypoxia-response elements (HRE), initiating gene transcription (see Fig. 2).

Conde et al. found that HIF- $1 \alpha$ is expressed during ischaemia, but disappears $24 \mathrm{~h}$ after hypoxia is reversed, then reappears in late reperfusion [15], suggesting recurrence of tissue hypoxia during the cell regenerative phase [16]. In human kidney allograft biopsies, upregulation of HIF- $1 \alpha$ is detected immediately after engraftment, at 10 14 days post procedure, but not after 3 months [17]. These findings suggest that renal hypoxia occurs not only during the acute phase of ischaemic injury but also during the recovery phase, presumably due to the activity of oxygen-consuming regenerative processes.

\section{HIF activation and fibrogenesis: antagonist or protagonist}

Current evidence is conflicting regarding the role of HIF in progression of CKD. Experiments using cobalt chloride $\left(\mathrm{CoCl}_{2}\right)$ and dimethyloxalyglycine (DMGO) to stabilise HIF and increase expression of HIF target genes in an ablation/ infarction mouse model showed up-regulation of vascular endothelial growth factor (VEGF), glucose transporter 1 (GLUT1) and cell proliferation, indicating a reno-protective effect of HIF [18]. Another study in mice assessed the relationship between HIF-1, ischaemic acute kidney injury (AKI) and the development of fibrosis by increasing HIF level using preischaemic pharmacological inhibition of HIF-propyl hydroxylases. Increased HIF level was associated with reduced fibrosis and less alpha-smooth muscle actin ( $\alpha$-SMA) expression at 21 day post ischaemia reperfusion injury (IRI) [19]. This antifibrotic effect was not observed when HIF-propyl hydroxylase inhibition was given after IRI. In addition, Kobayashi et al. documented reduced fibrosis in mice subjected to unilateral ureteral obstruction (UUO) and global activation of HIF [20].

In contrast to these observations, there is a significant body of evidence to support a pro-fibrotic role of HIF. Wang et al. showed that silencing HIF- $1 \alpha$ in a rat model of chronic renal ischaemia decreased collagen and $\alpha$-SMA induction [21]. Moreover, HIF- $1 \alpha$ knockout prevented transforming growth factor- $\beta 1$ (TGF- $\beta 1$ ) induced epithelial-to-mesenchymal transition (EMT) in mouse proximal tubular epithelial cells following unilateral ureteral obstruction (UUO) [22]. Our unpublished data shows that hypoxia or stabilisation of HIF- $1 \alpha$ is associated with inhibition of SMAD7 and increased in SMAD3 activity, also suggesting a pro-fibrotic role of HIF. Post-ischaemic renal fibrosis can occur through several mechanisms, including direct transcriptional regulation of pro-fibrotic genes, epithelial-to-mesenchymal transition (EMT) and induction of epigenetic changes. All of these mechanisms can be driven by HIF activation, either a. Normoxia

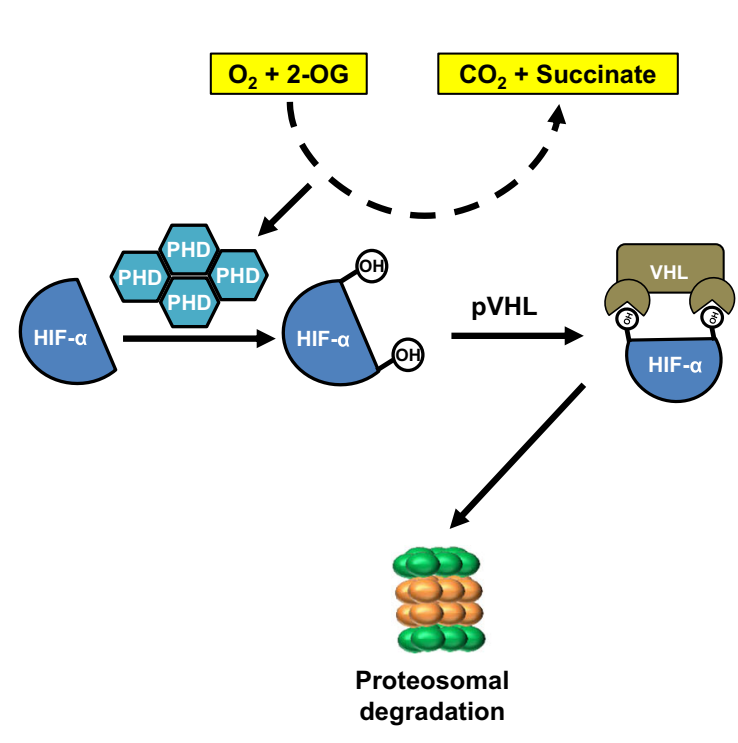

\section{b. Hypoxia}

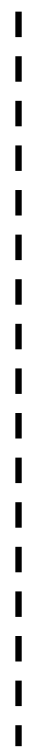

Fig. 2 HIF- $\alpha$ canonical pathway during a normoxia and $\mathbf{b}$ hypoxia 
through direct regulation or indirectly, involving crosstalk with multiple signalling pathways [23, 24], as discussed in the subsequent sections.

\section{Direct transcriptional regulation of pro-fibrotic genes by HIF}

HIF binding to HREs in gene promotor regions allows direct transcriptional regulation of many genes essential in promoting renal fibrosis. As examples, in a mouse glomerulosclerosis model, Baumann et al. has shown HIF- $1 \alpha$ binding to HREs in the promotor region of the collagen type-1 alpha 2 chain (COL1A2) gene [25]. Nuclear accumulation of HIF-1 $\alpha$ induced by ischaemia was shown to promote extracellular matrix deposition by renal proximal tubular epithelial cells by direct regulation of plasminogen activator inhibitor-1 (PAI-1) [26].

Exposure of human renal fibroblasts to hypoxia in vitro led to significant increase in Col-1 and tissue inhibitor of metalloproteinase (TIMP)-1 production, accompanied with decreased expression of collagenase [27]. Although hypoxia alone induced TGF- $\beta 1$, the introduction of an inhibitory anti-TGF- $\beta 1$ antibody had no effect in preventing hypoxiainduced Col-1 and TIMP-1 mRNA expression, suggesting a direct effect of HIF- $1 \alpha$ on gene transcription [27]. In addition, a study on human skin fibroblasts demonstrated the contribution of HIF- $1 \alpha$ to the development of post-ischaemic fibrosis by directly regulating pro-Collagen prolyl (P4HA1 and P4HA2) and lysyl (PLOD2) genes essential for collagen deposition, extracellular matrix stiffening and collagen fibre alignment (see Fig. 3) [28].

\section{HIF interaction with the TGF- $\beta$ pathway}

TGF- $\beta$ is one of the main mediators of renal fibrosis. A relationship between HIF and TGF- $\beta$ was shown by the increasing level of TGF- $\beta 1$ produced by tubular cells in response to hypoxia [29]. HIF has been shown to directly regulate the transcription of many genes involved in the TGF- $\beta$ pathway. In a glomerulosclerosis model, HIF- $1 \alpha$ was shown to form a complex with phophoSMAD3 at the COL1A2 promoter, inducing Col-1 synthesis [25]. Similar synergistic interaction of HIF and TGF- $\beta 1 /$ SMAD3 signalling has also been reported in the regulation of VEGF, endothelin and erythropoietin expression [24]. Furthermore, accumulation of HIF in the endothelial cells of endothelial specific propyl hydroxylase-2 knockout mice upregulated TGF- $\beta 1$ expression, resulting in significantly poorer renal function [30]. In a study using a renal tubular cell line in which transcription of HIF- $\alpha$ was absent, there was a decrease in basal and TGF- $\beta 1$ stimulated Col- 1 expression [31]. Altogether, these findings highlight the close interaction between HIF and TGF- $\beta$ pathway.
Despite being implicated in promoting fibrosis, TGF- $\beta$ has also been shown to have an immunosuppressive effect, which may be beneficial in a kidney transplant setting. Yoshimura et al. proposed several mechanisms by which TGF- $\beta$ inhibits the immune response [32]. These mechanisms include suppression of helper $\mathrm{T}$ cell differentiation, suppression of $\mathrm{T}$ cell activation and proliferation, suppression in macrophages, dendritic cells (DCs) and natural killer (NC) cells, conversion of naive $\mathrm{T}$ cells to regulatory $\mathrm{T}$ cells, and inhibition of cytokine production (IL-2, IL-4). The effect of the interaction between HIF and TGF- $\beta$ pathway on the recipients' immune status, and how this may affect long-term allograft function is not known. However, profiling of biopsy tissues from chronic allograft nephropathy (CAN) patients showed significantly higher expression of both HIF- $1 \alpha$ and TGF- $\beta 1$ compared to the group without CAN [33].

\section{HIF interaction with other pro-fibrotic pathways}

Post-ischaemic induction of HIF also plays a pro-fibrotic role by indirect crosstalk with other pro-fibrotic pathways including Notch, NF-KB and PI3K/Akt pathways [23]. The interaction between HIF and these other pathways is complex (see Fig. 3). HIF can increase the transcription of proteins involved in these other pathways [30, 34]. HIF can also interact with other transcription factors, augmenting their transcriptional activity [35]. In addition, these other pathways can increase HIF gene expression, creating a positive feedback loop [35]. Recently, a transcription factor CCAAT/enhancer-binding protein $\delta(C E B P D)$ was discovered as a potential link between hypoxia and inflammation. CEBPD is known to be rapidly induced by inflammatory cytokines, such as IL-1 $\beta$, in a NF- $\mathrm{KB}$ dependent manner. In both an acute and chronic murine model of renal hypoxia, CEBPD was induced in the nuclei of tubular epithelial cells and by direct promoter binding increased HIF transcription and activity [36].

\section{Endothelial injury and vascular rarefaction}

Depending on its severity, ischaemia alone may cause endothelial injury/dysfunction. As a consequence, the endothelium is no longer able to serve as an adequate barrier between the insterstitium and the vascular compartment, loses its ability to control adhesion and infiltration of immune/inflammatory cells and fails to regulate key haemostatic mechanisms [37]. Endothelial cells contribute to progression of IRI by two main mechanisms; (1) increased permeability and (2) vasomotor dysregulation.

Increased endothelial permeability can be attributed to direct injury to the endothelial cells, alterations to the actin cytoskeleton, loss of cell-to-cell junctions and enhanced leukocyte-endothelial interactions $[38,39]$. In normal 


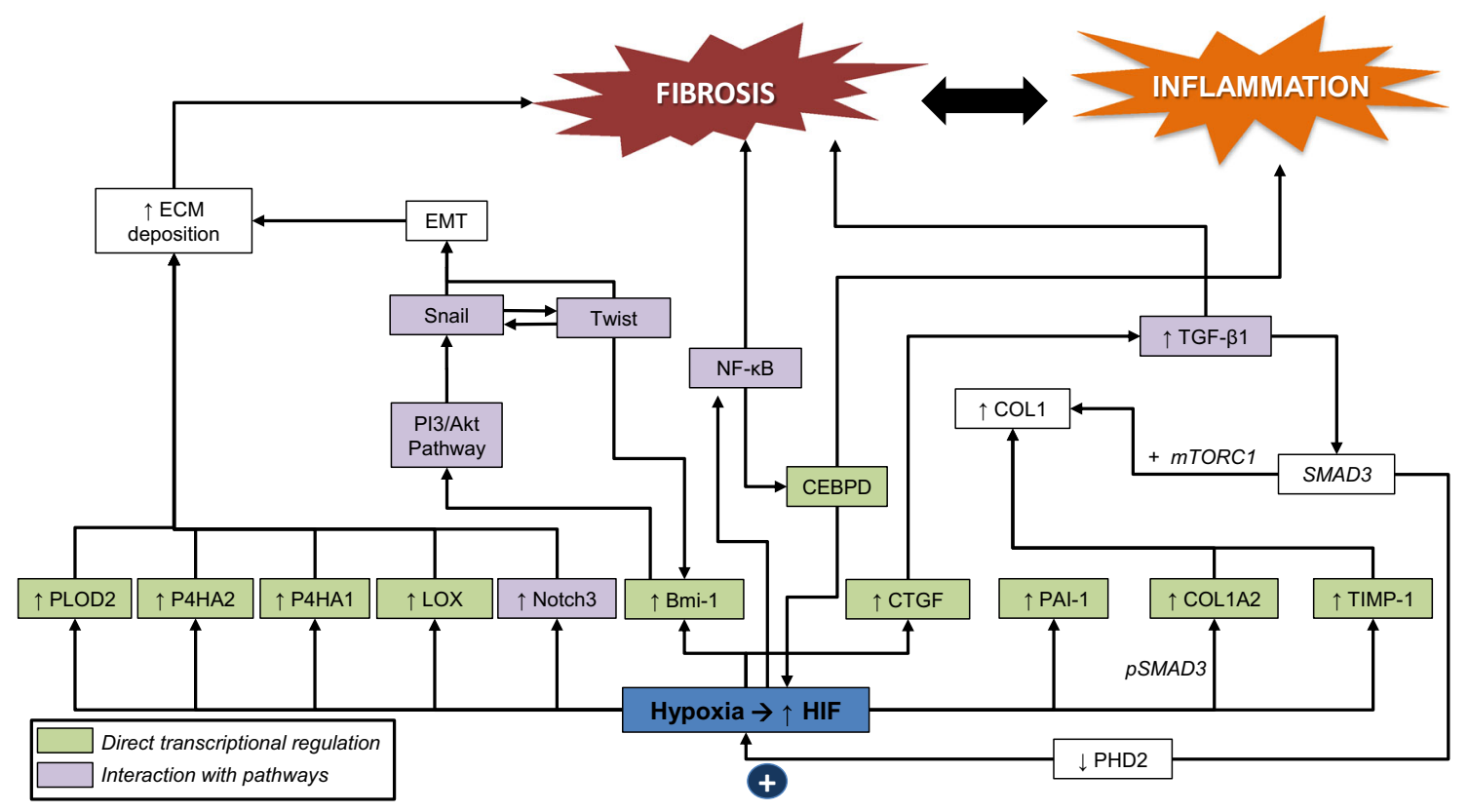

Fig. 3 Contribution of HIF- $\alpha$ to the development of post-ischaemic fibrosis

conditions, the endothelium is maintained in a monolayer by the formation of intercellular junctional complexes. These junctional complexes interact with the cell cytoskeleton and other intracellular proteins, and this interaction is highly sensitive to physiological/pathophysiological stimuli, such as ROS, cytokines, lipid mediators and proteases [37]. Release of pro-inflammatory mediators and ROS during IRI will induce phosphorylation, internalisation and degradation of these junctional complexes resulting in endothelium structural damage [40].

Increased levels of prostaglandin $\mathrm{H} 2$, leukotrienes $\mathrm{C} 4$ and $\mathrm{D} 4$, increased sympathetic activity and reduced nitric acid synthetase activity have all been documented following endothelial injury, leading to vasoconstriction. [41]. The injured endothelium will also release chemotactic cytokines, increasing leukocytes-endothelial adhesion and release of vasoactive, inflammatory cytokines, which in turn amplify the vasoconstriction that occurs [41]. Exacerbation of hypoxia is closely tied to changes in outer medullary haemodynamic, mainly as a result of IRI induced inflammation, which reduces naturally occurring anti-coagulant activity crucial to prevent micro-coagulapathy [39]. The combination of excessive vasoconstriction, leukocyte activation and subsequent activation of coagulation pathways may lead to mechanical obstruction of the capillary network and reduction in blood vessel patency, which further compromises microcirculatory physiology, especially in the outer renal medulla (see Fig. 4). As a consequence, further ischaemia will ensue, amplifying the initial insult as well as affecting subsequent repair processes.

Significant reduction in peri-tubular capillaries (PTC) density has been suggested as a possible factor that makes the post-ischaemic kidney susceptible to further loss of function. Using the bilateral ischaemia reperfusion rat model, Basile et al. showed a 30-50\% permanent reduction in PTCs in the outer medulla despite normal tubular morphology. Ischaemic kidneys subsequently developed tubulointerstitial fibrosis [42]. Similar findings were also reported in a kidney transplant cohort. Loss of PTC during the first 3 months post-transplant was associated with increased interstitial fibrosis, tubular atrophy and reduced renal function [43].

Basile et al. [44] proposed three possible mechanisms on how post-ischaemic PTC loss may lead to the development of long-term fibrosis: (1) exacerbation of pre-existing hypoxia, (2) changes in outer medullary haemodynamics, which is linked to impairment in sodium homeostasis, predisposing the kidney to the development of sodium sensitive hypertension and (3) endothelial-to-mesenchymal transition (EndoMT), which promotes proliferation of new fibroblasts. Acute hypoxia has been linked with the activation of profibrotic pathway, and there is strong evidence available to show that PTC loss increases interstitial hypoxia even after the initial acute hypoxic episode has resolved [45]. Alterations in outer medullary haemodynamics affect tubule-glomerular feedback mechanisms that are involved in the regulation of sodium homeostasis, leading to the development hypertension [46]. EndoMT is a potential source of interstitial fibroblasts after hypoxia. A study on bilateral ischaemic kidney mouse model showed prominent co-existing staining of endothelium (CD31 or cablin) and the mesenchymal marker (S100A4) within $6 \mathrm{~h}$ after hypoxia, which was sustained for at least 7 days [47]. The role of EndoMT is still not clearly understood but there in increasing that data 


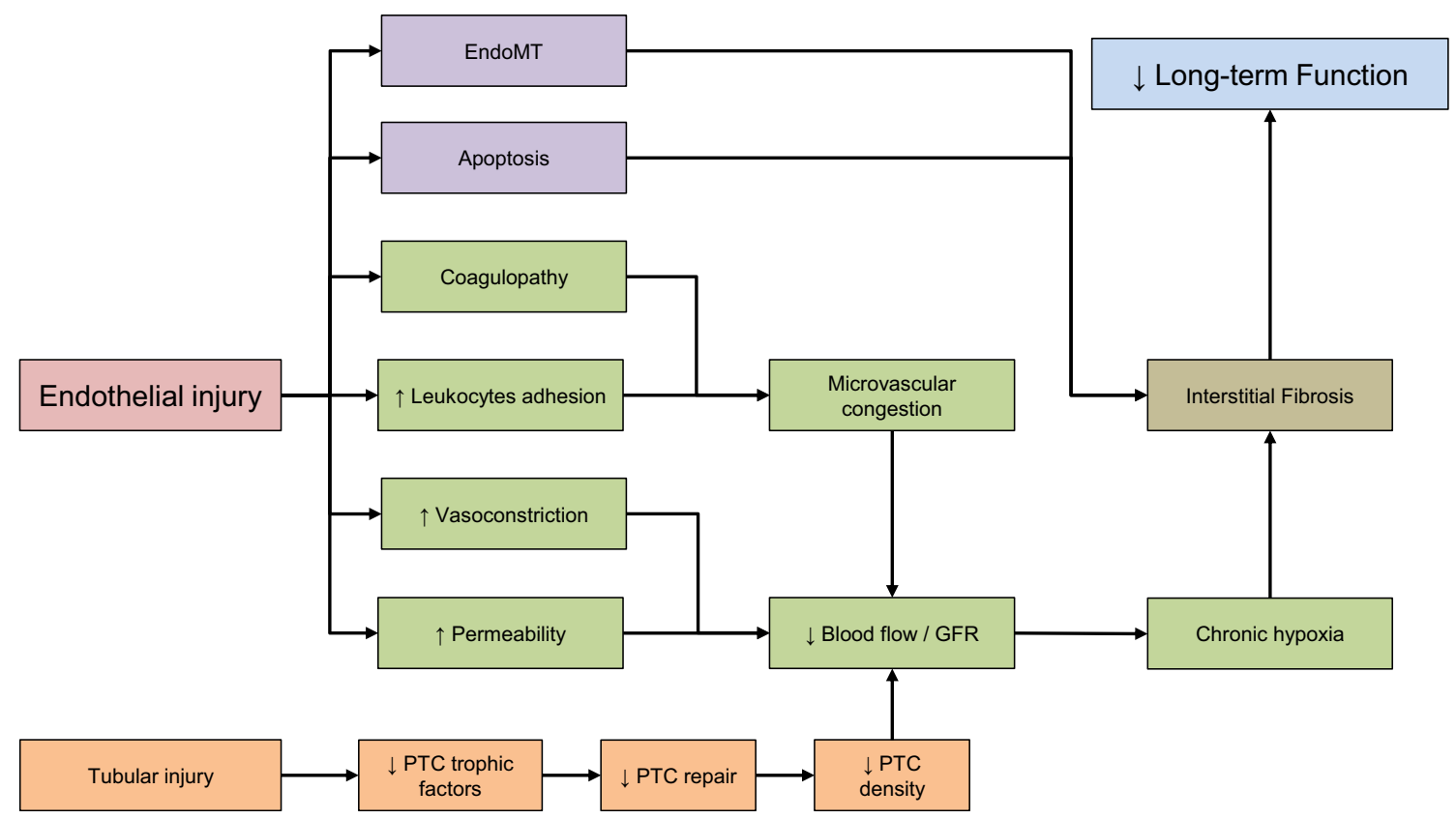

Fig. 4 Mechanical obstruction of the capillary network and reduction in blood vessel patency

suggests it makes a significant contribution, in combination with the loss of endothelial regenerative capacity, to the progression of chronic kidney damage [47, 48].

\section{The role of inflammation and the immune system}

Ischaemia reperfusion injury is a result of various mechanisms, including the host inflammatory/immune response. The initiation of inflammation occurs during ischaemia, whilst post-ischaemic events, such as ROS generation, amplifies the response. Therefore, the ischaemic kidney is not merely the target of immune activation. Instead, it plays an active role in promoting immune activation. The acute inflammatory component of IRI involves the expression of cell surface adhesion molecules. To evaluate the effect of IRI on the expression of these adhesion molecules, rat renal grafts were cold preserved for 2, 4, 6, 12, 24 and $48 \mathrm{~h}$, before being transplanted into syngeneic recipients [49]. The study revealed that longer duration of cold-ischaemia led to loss of endothelial integrity and increased expression of VCAM-1. Ischaemic grafts also displayed enhanced intra-graft pro-coagulant capacity and a worse tubular necrosis [49]. Unexpectedly, renal function measured by creatinine and urea were similar in all groups. This implies that there are potentially injurious processes occurring after moderate IRI that are clinically undetectable. Whether the same is true in patients receiving allografts from marginal donors but who do not develop DGF remains an important research question.

\section{The role of neutrophils and macrophages}

Neutrophil adhesion to injured endothelial cells is a rapid and important component in the initiation of damage in the ischaemic kidney. Neutrophils have been shown to migrate into the transplanted organ within $6 \mathrm{~h}$ of reperfusion and are attracted by a set of chemokines, including CXCL8 (IL-8), CXCL10, RANTES, IL-17 and MCP-I [50-53]. Damaged cells will be killed by neutrophils by direct phagocytosis or degranulation, releasing proteases, myeloperoxidase, nitrogen species, antimicrobial peptides and cytokines, which further contribute to the generation of ROS [54]. Recruitment of neutrophils also involves endothelial cell expression ICAM1, E and $\mathrm{P}$ selectin, which cross-talk with integrins and L-selectin on neutrophils $[51,55,56]$. Inhibiting the accumulation of neutrophils in the kidney may prevent acute kidney injury $[53,56-58]$. In contrast, other studies have failed to reproduce beneficial effects of neutrophil depletion and suggest neutrophil independent mechanism in the pathophysiology of acute tubular injury $[59,60]$. Nevertheless, the majority of evidence supports a role for neutrophils in the development of post-ischaemic injury, by mechanisms including obstruction of renal microvasculature and release of free radicals and proteases [61].

Several studies have observed a decrease in IRI severity after macrophages depletion prior to injury $[62,63]$ indicting a role for macrophages in promoting tubular injury during the initial phase of IRI. However, suppressing macrophage function during the repair process has been shown to suppress tubular proliferation, thus impairing the normal recovery process. Therefore, the role of macrophages in renal response to 
IRI is complex. Pre-clinical studies have described the involvement of macrophages in the early inflammatory response, during cellular regeneration and tissue repair as well as during the development of fibrosis. These diverse roles are played by different sub-types of macrophages based on their activation and functional states. Classical activation of macrophages typically involves interferon gamma (IFN $\gamma$ ). Ischaemia-induced cellular injury also produces dangerassociated molecular patterns (DAMPs), which will be recognised by pattern recognition receptors (PRRs) and contribute to classical macrophage activation. These classically activated M1 macrophages are pro-inflammatory and associated with tissue damage. However, they also play an important role in clearing apoptotic cells and debris, thereby initiating repair process [64]. Alternatively activated macrophages include M2a macrophages, which are responsible for wound healing and M2b macrophages, also known as immunoregulatory macrophages. M2a macrophages are activated through IL-4/IL-13 binding to IL-4 receptor, which leads to production of growth factors, collagen precursor synthesis and generation of extracellular matrix. M2b macrophages regulate inflammatory response by producing of immunosuppressive cytokines, IL-10 and TGF- $\beta$. Production of TGF- $\beta$ limits inflammation, but at the same time may contribute to activation of profibrotic pathways. When injury persists, chemokines, macrophage colony-stimulating factors (M-CSF) and IL-34 are secreted to sustain recruitment and retention of macrophages [65]. Blockade of the M-CSF receptor has a protective effect following experimental transplantation [66]. Retention of $\mathrm{M} 2 \mathrm{~b}$ macrophages in the injured tissue will produce macrophage-derived factors, which subsequently activate and support myofibroblasts, inducing extracellular matrix deposition and fibrosis. The signals responsible for retaining pro-fibrotic macrophages in the kidney remain unclear, but studies using unilateral ureteral obstructive (UUO) rodent model suggest a role for the chemokine receptors CCR1, CCR2, CX3CR1 [65].

\section{The role of the complement system}

The complement system has been well identified as an important, early mediator of the post-ischaemic inflammatory response [67, 68]. Activation of complement is an important factor in the progression of renal disease, and targeting complement has been an attractive therapeutic option due to its involvement in both innate and adaptive immune response to IRI [69, 70]. Ischaemic insult to the kidney has been shown to involve the anaphylotoxins, $\mathrm{C} 3 \mathrm{a}$ and $\mathrm{C} 5 \mathrm{a}$, acting through their respective receptors (C3aR and $\mathrm{C} 5 \mathrm{aR})$. Stimulation of $\mathrm{C} 3 \mathrm{a} /$ $\mathrm{C} 5$ a receptors during IRI was shown to increase proinflammatory cytokine/chemokine production and tubular injury. The membrane attack complex C5b-9 has also been shown to contribute to the progression of renal damage [71].
Recently, C-type lectin collectin-11 (CL-11/Colec11) was discovered as an activator of mannan-binding lectin (MBL) pathway in the kidney in response to ischaemia. CL-11 acts by recognising L-fucose on kidney tubules following ischaemia [72]. The study showed that global or kidney-specific deficiency of CL-11 reduces post-ischaemic tubular injury and functional loss [72].

\section{The role of natural killer cells, dendritic cells and lymphocytes}

Substantial evidence is available to link natural killer (NK) and NKT cells, renal dendritic cells (DCs), T cells and B cells to early IRI, mainly linking their actions to direct targeting of injured tubular and endothelial cells, activation of neutrophils and macrophages, and secretion of pro-inflammatory cytokines, such as IFN- $\gamma$, TNF- $\alpha$, IL-4 and IL-10. If NK and NKT cell function is reduced, the severity of renal injury following IRI is also reduced [73-75]. DCs contribute to post-ischaemic kidney injury by the secretion of TNF [76]. Biopsies taken from DGF patients suggested an association between DGF and acute rejection due to an imbalance between myeloid DCs (involved in graft rejection) and plasmacytoid DCs (which may play role in graft tolerance) [77].

Although initially regarded as by-standers, current evidence suggests an active role for $\mathrm{T}$ cells in the pathogenesis of IRI. Depletion of CD4 and CD8 T cells in murine IRI has been shown to improve renal function and reduce neutrophil infiltration and tubular atrophy [78]. Furthermore, reconstitution of $\mathrm{T}$ cells in $\mathrm{T}$ cell-deficient mice restores injury to the level seen in normal mice [79]. Depletion of either $\alpha \beta$ or $\gamma \delta$ T-cells in mice was associated with reduction in renal injury [80]. Nevertheless, a subset of $\mathrm{T}$ cells is also recognised to play a role in preventing injury and promoting repair. Pre- and post-ischaemic adoptive transfer of regulatory $\mathrm{T}$ cells has been shown to protect the kidney from ischaemic injury, reduce TNF- $\alpha$ and IFN- $\gamma$ production and accelerate repair [81, 82].

$\mathrm{B}$ cells are involved in the adaptive immune response to IRI. To date, studies have shown a predominantly harmful effect of post-ischaemic B cell activation [83]. Depleting B cell in mice was shown to improve renal function and reduce tubular injury after ischaemia [84]. A study by Jang et al. documented that B cell-deficient mice subjected to ischaemia showed more tubular proliferation, less tubular atrophy and higher expression of IL-10 and VEGF [85]. Adoptive transfer of $\mathrm{B}$ cells into these mice blocked this effect, suggesting that B cells may interfere with postischaemic repair processes. In contrast, another study found worse post-ischaemic renal injury in mice lacking all mature B cells [86], suggesting a more complex and divergent role for B cells in the progression of IRI. 


\section{Tubular recovery and maladaptive repair}

The proximal tubule is the main site of injury in acute ischaemic kidney. Consequently, the severity and recurrence of injury at this site acts as an important factor in determining reversibility of the damage and progression to long-term organ failure. Severe and repeated injuries induce worse interstitial fibrosis, distal tubular injury, glomerulosclerosis and atubular glomeruli [87]. Ischaemic tubular injury is most evidently found in the S3 segment of the proximal tubule and initially results in loss of cytoskeletal integrity [88]. The degree of cytoskeletal alteration depends on the severity and duration of ischaemia. This loss of cytoskeletal integrity further modifies cellular polarity, cell-to-cell interactions as well as cell-tomatrix interactions, and loss of function [89].

Kidney tubular epithelial cells have been shown to play an active role in progression of post-ischaemic tissue damage through several mechanisms (see Fig. 5). There is substantial evidence that TECs release pro-inflammatory and chemotactic cytokines in response to IRI [89-91], which includes TNF-a, IL-6, IL-1B and TGF-B in addition to chemokines, such as MCP-1, IL-8, RANTES and ENA-78 [90]. This leads to recruitment of immune cells, important for subsequent repair following IRI but also to the damage that occurs. In addition, damaged epithelial cells produce DAMPs, which act as warning signals by activating a series of Toll-like receptors (TLR2, TLR3 and TLR4) and express complement receptors and other co-stimulatory molecules which regulate $\mathrm{T}$ lymphocyte activity $[41,92,93]$. Downregulating the expression of TLR-2 on kidney parenchymal cells was shown to reduce the level of pro-inflammatory cytokines (IL-1 $\beta$, IL-6, MCP-1 and Keratinocyte Chemoattractant) produced by the kidney, thus providing functional and structural protection against IRI [92]. $\mathrm{Wu}$ et al. demonstrated upregulation of TLR4 post IRI in TECs and inhibiting TLR4 reduced the severity of IRI [93].
Furthermore, TLR4 knockout mice showed reduced tubular injury with better preservation of renal function after induction of IRI compared with wild type mice [94].

Dedifferentiation of proximal tubule cells caused by IRI may not always be followed by complete re-differentiation and resolution of injury. Rodent kidneys subjected to IRI still had a proportion of abnormal tubules with flat epithelium without brush borders after 14 days. These cells were morphologically abnormal, atrophic and growth arrested. As well as showing strong TGF- $\beta$ signalling, these abnormal cells also showed persistent loss of phosphate and tension homologue (PTEN) associated with increased expression of vimentin, pro-fibrotic c-Jun N-terminal kinase (JNK) activation and platelet-derived growth factor (PDGF)-B production [95].

TEC secretion of cytokines and growth factors is important for cell survival and repair, however, this should halt once complete regeneration is achieved [96, 97]. A study of five different mouse models of acute kidney injury revealed large numbers of proximal tubule were arrested in the $\mathrm{G} 2 / \mathrm{M}$ phase of the cell cycle, which is associated with persistent activation of JNK signalling and higher production of COL4AI and ACTA2 mRNA levels [98]. A number of studies by Venkatachalam et al. also showed that tubular cell arrest and atrophy is linked with increased secretion of fibrogenic peptides, which accelerates proliferation of interstitial pericytes/fibroblasts through multiple pathways, including PI3K-Akt-mTOR, ERK-MAPK, JNK-MAPK and TGF- $\beta$ pathways [96, 99, 100], eventually resulting in nephron loss. Based on these finding, several authors have investigated the potential usage of cell cycle arrest biomarkers in the detecting acute kidney injury [101].

Tubular cells maladaptive repair is also associated with activation of several other pro-fibrotic pathways, such as Notch and Wnt signalling. Recent work using a mouse model with inducible proximal tubule Wnt1 secretion

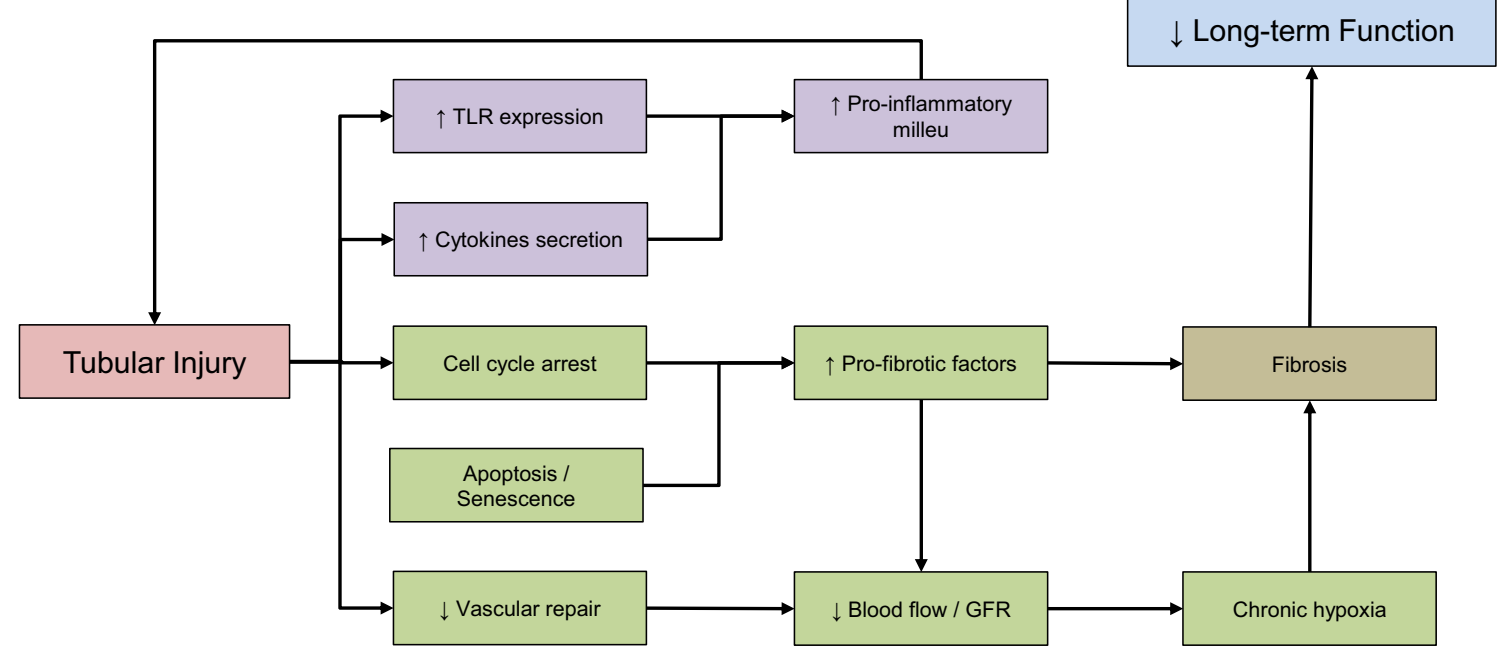

Fig. 5 Kidney tubular epithelial cells playing an active role in progression of post-ischaemic tissue damage through several mechanisms 
displayed interstitial myofibroblast activation and proliferation and increased matrix protein production [102]. Interestingly, no evidence of inflammatory cytokine expression, leukocyte infiltration or epithelial injury were detected in these fibrotic kidneys, demonstrating direct paracrine Wnt1 activity in initiating interstitial fibrosis through tubulointerstitial crosstalk [102].

\section{Epigenetic changes}

Recent findings highlight the pivotal role of epigenetic changes caused by acute IRI in damage progression resulting in renal fibrosis and long-term deterioration of function. Hypoxia has been proven to induce epigenetic changes in the form of DNA methylation, histone modification, alteration in chromosome conformation, differentially expressed long non-coding RNAs (lncRNAs) and microRNAs (miRNAs) [103, 104]. Affected cells have been shown to store these changes in form of "memory" $[103,105]$. In respect to IRI, this "hypoxic memory" may sustain initial pathological alteration in homeostasis or induce new changes that result in transition from acute to chronic kidney injury. Animal models of acute kidney injury have demonstrated that "hypoxic memory" can promote pro-inflammatory and pro-fibrotic gene expression, such as monocyte chemoattractant protein-1, TGF- $\beta 1$, and collagen [103]. The development of renal fibrosis has been associated with several DNA methylation and histone modifications. Comparison of the methylation profile of fibroblasts derived from fibrotic and non-fibrotic kidneys showed distinct methylation patterns, including hypermethylation of RAS protein activator-like 1 gene [106]. In UUO model, TGF- $\beta$ has been shown to increase histone $\mathrm{H} 3$ lysine methylation, which increased expression of extracellular matrix gene connective tissue growth factor, Collagen-1 and plasminogen activator inhibitor-1 in mesangial cells. The study also showed inhibition of renal fibroblast accumulation through blocking of class I histone deacetylates $[107,108]$. Moderate IRI has been shown to increase TGF- $\beta 1$ and CTGF protein production, which in turn initiated epigenetic changes in fibroblasts [98]. Bechtel et al. documented hypermethylation of RASAL1 gene loci [106], which in turn persistently activated Ras, resulting in transformation of fibroblasts to myofibroblasts secreting collagen in a growth-factor independent manner [109]. As described in a previous section of this review, long-term effect of acute IRI is partly mediated by EMT. A cell model of TGF- $\beta$-mediated EMT revealed global altered methylation of several heterochromatins, highlighting the role of epigenetic changes in the pathogenesis of IRI progression [110].

Extensive investigations have been made to link miRNA with renal pathologies, such as acute kidney injury, fibrosis, polycystic kidney and neoplasm. In the kidney transplant setting, miRNA expression has been profiled in association with rejection, interstitial fibrosis, tubular atrophy as well as ischaemia and reperfusion injury. In the context of IRI progression to fibrosis, several miRNAs have been examined, among many are miR-363, miR-192, miR-200, miR-21-, miR-34a, miR-155 and miR-127 [111-113]. Our unpublished data shows that the up-regulation of miR-21 that occurs following IRI inhibits SMAD7 activity, contributing to exaggerated tubular cell responses to TGF- $\beta 1$ and upregulation of

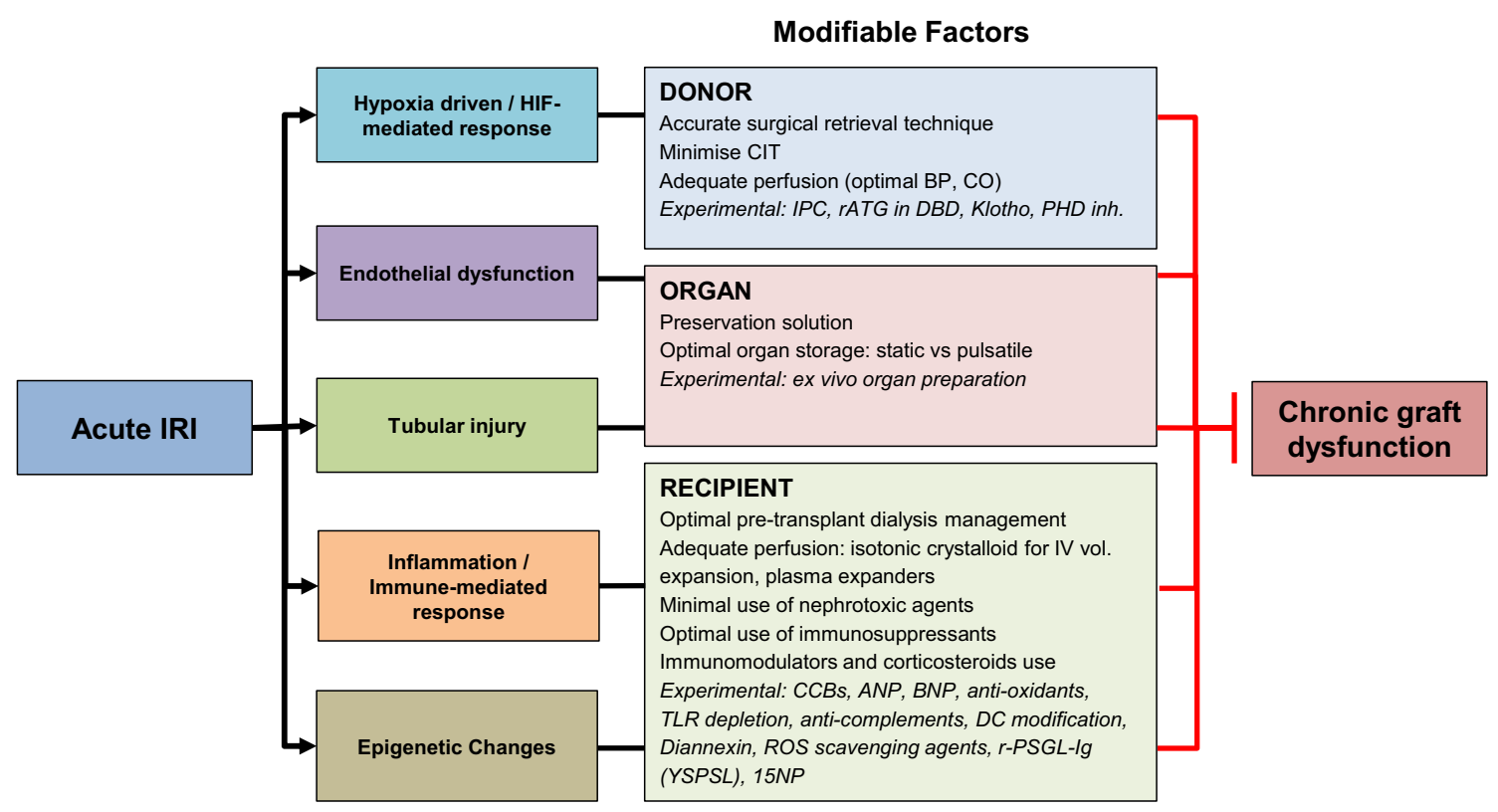

Fig. 6 Factors that can be modified to prevent the progression of acute IRI to chronic graft dysfunction. IRI ischaemia-reperfusion injury 
pro-fibrotic markers ( $\alpha$-SMA, collagen type-1) and downregulation of E-cadherin.

\section{Concluding remarks}

We have reviewed currently available evidence on potential mechanisms of acute ischaemic renal injury progression to long-term organ dysfunction. Despite the lack of evidence to prove a causative association between $\mathrm{AKI}$ and $\mathrm{CKD}$, strong epidemiological correlates and substantial biological mechanistic links clearly point to the impact of early post-ischaemic events on the development of long-term graft dysfunction. Biological links that connect acute IRI to chronic dysfunction include; (1) HIF-1 $\alpha$ driven changes, (2) endothelial and epithelial injury that leads to cellular senescence and maladaptive repair, (3) inflammation/immune system driven processes and (4) epigenetic alteration, all of which may lead to chronic hypoxia and fibrosis as the main underlying pathophysiology. The severity and frequency of the initial insult are crucial factors in determining possible occurrence of long-term consequences. It is also important to acknowledge the active roles played by the cells within the kidney. This is especially of importance in kidney transplant setting, as the repair mechanisms following IRI will vary greatly, depend on the characteristics of the donor kidney (donor type, age, ischaemic time, etc.), characteristics of the recipient (age, underlying disease, co-morbidities, etc.) and various perioperative parameters (haemodynamic fluctuations, warm ischaemia time, the use of prophylaxis for IRI, etc.). In addition, unlike native kidneys, the cellular and molecular effects of IRI in the transplanted kidneys are influenced by immunosuppressive agents. This will have an effect in the kidney's susceptibility to IRI and its capacity for repair. Modification of the contributing factors to IRI through careful donor selection and preventative procedures are essential to prevent long-term consequences of IRI (see Fig. 6). In the era of rising CKD incidence and where extended criteria donor organs are increasingly utilised, our understanding of IRI-induced molecular events is pivotal in the search for interventions to improve organ quality, thus achieving longer graft survival.

Funding information The study is supported by the National Institute of Health Research Cambridge Biomedical Research Centre and the NIHR Blood and Transplant Research Unit in Organ Donation and Transplantation at the University of Cambridge in collaboration with Newcastle University and in partnership with NHS Blood and Transplant (NHSBT). This is also supported by the Indonesian Endowment Fund for Education.

\section{Compliance with ethical standards}

Conflict of interest The authors declare that they have no conflict of interest.
Open Access This article is distributed under the terms of the Creative Commons Attribution 4.0 International License (http:// creativecommons.org/licenses/by/4.0/), which permits unrestricted use, distribution, and reproduction in any medium, provided you give appropriate credit to the original author(s) and the source, provide a link to the Creative Commons license, and indicate if changes were made.

\section{References}

1. Heung M, Chawla LS (2014) Acute kidney injury: gateway to chronic kidney disease. Nephron Clin Pract 127:30-34

2. Mammen C, Al Abbas A, Skippen P, Nadel H, Levine D, Collet JP, Matsell DG (2012) Long-term risk of CKD in children surviving episodes of acute kidney injury in the intensive care unit: a prospective cohort study. Am J Kidney Dis 59:523-530

3. Yarlagadda SG, Coca SG, Formica RN Jr, Poggio ED, Parikh CR (2009) Association between delayed graft function and allograft and patient survival: a systematic review and meta-analysis. Nephrol Dial Transplant 24:1039-1047

4. Safran M, Kim WY, O'Connell F, Flippin L, Günzler V, Horner JW, DePinho RA, Kaelin WG (2006) Mouse model for noninvasive imaging of HIF prolyl hydroxylase activity: assessment of an oral agent that stimulates erythropoietin production. Proc Natl Acad Sci U S A 103:105-110

5. Ngo JP, Kar S, Kett MM, Gardiner BS, Pearson JT, Smith DW, Ludbrook J, Bertram JF, Evans RG (2014) Vascular geometry and oxygen diffusion in the vicinity of artery-vein pairs in the kidney. Am J Physiol Renal Physiol 307:F1111

6. Tullius SG, Reutzel-Selke A, Egermann F, Nieminen-KelhÄ M, Jonas S, Bechstein WO, Volk H-D, Neuhaus P (2000) Contribution of prolonged ischemia and donor age to chronic renal allograft dysfunction. J Am Soc Nephrol 11:1317-1324

7. Jayle C, Faure JP, Thuillier R, Goujon JM, Richer JP, Hauet T (2009) Influence of nephron mass and a phosphorylated 38 mitogen-activated protein kinase inhibitor on the development of early and long-term injury after renal warm ischaemia. Br J Surg 96:799-808

8. Wong G, Teixeira-Pinto A, Chapman JR, Craig JC, Pleass H, McDonald S, Lim WH (2017) The impact of Total ischemic time, donor age and the pathway of donor death on graft outcomes after deceased donor kidney transplantation. Transplantation 101: $1152-1158$

9. Nangaku M (2006) Chronic hypoxia and tubulointerstitial injury: a final common pathway to end-stage renal failure. J Am Soc Nephrol 17:17-25

10. Heyman SN, Khamaisi M, Rosen S, Rosenberger C (2008) Renal parenchymal hypoxia, hypoxia response and the progression of chronic kidney disease. Am J Nephrol 28:998-1006

11. Tanaka S, Tanaka T, Nangaku M (2014) Hypoxia as a key player in the AKI-to-CKD transition. Am J Physiol Renal Physiol 307: F1187

12. Burslem GM, Kyle HF, Nelson A, Edwards TA, Wilson AJ (2017) Hypoxia inducible factor (HIF) as a model for studying inhibition of protein-protein interactions. Chem Sci 8:4188-4202

13. Tanaka $\mathrm{T}$ (2017) A mechanistic link between renal ischemia and fibrosis. Med Mol Morphol 50:1-8

14. Rabinowitz MH (2013) Inhibition of hypoxia-inducible factor prolyl hydroxylase domain oxygen sensors: tricking the body into mounting orchestrated survival and repair responses. J Med Chem 56:9369-9402

15. Conde E, Alegre L, Blanco-Sanchez I, Saenz-Morales D, AguadoFraile E, Ponte B, Ramos E, Saiz A, Jimenez C, Ordonez A, 
Lopez-Cabrera M, del Peso L, de Landazuri MO, Liano F, Selgas R, Sanchez-Tomero JA, Garcia-Bermejo ML (2012) Hypoxia inducible factor 1-alpha (HIF-1 alpha) is induced during reperfusion after renal ischemia and is critical for proximal tubule cell survival. PLoS One 7:e33258

16. Nangaku M, Rosenberger C, Heyman SN, Eckardt KU (2013) Regulation of hypoxia-inducible factor in kidney disease. Clin Exp Pharmacol Physiol 40:148-157

17. Rosenberger C, Pratschke J, Rudolph B, Heyman SN, Schindler R, Babel N, Eckardt KU, Frei U, Rosen S, Reinke P (2007) Immunohistochemical detection of hypoxia-inducible factor-1alpha in human renal allograft biopsies. J Am Soc Nephrol 18:343351

18. Deng A, Arndt MA, Satriano J, Singh P, Rieg T, Thomson S, Tang T, Blantz RC (2010) Renal protection in chronic kidney disease: hypoxia-inducible factor activation vs. angiotensin II blockade. Am J Physiol Renal Physiol 299:F1365-F1373

19. Kapitsinou PP, Jaffe J, Michael M, Swan CE, Duffy KJ, EricksonMiller CL, Haase VH (2012) Preischemic targeting of HIF prolyl hydroxylation inhibits fibrosis associated with acute kidney injury. Am J Physiol Renal Physiol 302:F1172-F1179

20. Kobayashi H, Gilbert V, Liu Q, Kapitsinou PP, Unger TL, Rha J, Rivella S, Schlondorff D, Haase VH (2012) Myeloid cell-derived hypoxia-inducible factor attenuates inflammation in unilateral ureteral obstruction-induced kidney injury. J Immunol 188:51065115

21. Wang Z, Zhu Q, Li PL, Dhaduk R, Zhang F, Gehr TW, Li N (2014) Silencing of hypoxia-inducible factor-1alpha gene attenuates chronic ischemic renal injury in two-kidney, one-clip rats. Am J Physiol Renal Physiol 306:F1236-F1242

22. Higgins DF, Kimura K, Bernhardt WM, Shrimanker N, Akai Y, Hohenstein B, Saito Y, Johnson RS, Kretzler M, Cohen CD, Eckardt KU, Iwano M, Haase VH (2007) Hypoxia promotes fibrogenesis in vivo via HIF-1 stimulation of epithelial-tomesenchymal transition. J Clin Invest 117:3810-3820

23. Liu J, Wei Q, Guo C, Dong G, Liu Y, Tang C, Dong Z (2017) Hypoxia, HIF, and associated signaling networks in chronic kidney disease. Int J Mol Sci 18:1-17

24. Higgins DF, Kimura K, Iwano M, Haase VH (2008) Hypoxiainducible factor signaling in the development of tissue fibrosis. Cell Cycle 7:1128-1132

25. Baumann B, Hayashida T, Liang X, Schnaper HW (2016) Hypoxia-inducible factor-1alpha promotes glomerulosclerosis and regulates COL1A2 expression through interactions with SMAD3. Kidney Int 90:797-808

26. Li X, Kimura H, Hirota K, Kasuno K, Torii K, Okada T, Kurooka H, Yokota Y, Yoshida H (2005) Synergistic effect of hypoxia and TNF-alpha on production of PAI-1 in human proximal renal tubular cells. Kidney Int 68:569-583

27. Norman JT, Clark IM, Garcia PL (2000) Hypoxia promotes fibrogenesis in human renal fibroblasts. Kidney Int 58:2351-2366

28. Gilkes DM, Bajpai S, Chaturvedi P, Wirtz D, Semenza GL (2013) Hypoxia-inducible factor 1 (HIF-1) promotes extracellular matrix remodeling under hypoxic conditions by inducing P4HA1, P4HA2, and PLOD2 expression in fibroblasts. J Biol Chem 288: 10819-10829

29. Orphanides C, Fine LG, Norman JT (1997) Hypoxia stimulates proximal tubular cell matrix production via a TGF-beta1independent mechanism. Kidney Int 52:637-647

30. Wang S, Zeng H, Chen ST, Zhou L, Xie XJ, He X, Tao YK, Tuo QH, Deng C, Liao DF, Chen JX (2017) Ablation of endothelial prolyl hydroxylase domain protein-2 promotes renal vascular remodelling and fibrosis in mice. J Cell Mol Med 20:1-12

31. Basu RK, Hubchak S, Hayashida T, Runyan CE, Schumacker PT, Schnaper HW (2011) Interdependence of HIF-1alpha and TGFbeta/Smad3 signaling in normoxic and hypoxic renal epithelial cell collagen expression. Am J Physiol Renal Physiol 300:F898F905

32. Yoshimura A, Muto G (2011) TGF- $\beta$ function in immune suppression. In: Ahmed R, Honjo T (eds) Negative co-receptors and ligands. Springer Berlin Heidelberg, Berlin, pp 127-147

33. Lee S, Kim DJ, Park MG, Park SK, Kim JS, Hyun SJ, Oh JE, Nam ES, Joo SH (2008) Expression of transforming growth factorbeta1 and hypoxia-inducible factor-1alpha in renal transplantation. Transplant Proc 40:2147-2148

34. Du R, Xia L, Ning X, Liu L, Sun W, Huang C, Wang H, Sun S (2014) Hypoxia-induced Bmil promotes renal tubular epithelial cell-mesenchymal transition and renal fibrosis via PI3K/Akt signal. Mol Biol Cell 25:2650-2659

35. Luo R, Zhang W, Zhao C, Zhang Y, Wu H, Jin J, Zhang W, Grenz A, Eltzschig HK, Tao L, Kellems RE, Xia Y (2015) Elevated endothelial hypoxia-inducible factor-1alpha contributes to glomerular injury and promotes hypertensive chronic kidney disease. Hypertension 66:75-84

36. Yamaguchi J, Tanaka T, Eto N, Nangaku M (2015) Inflammation and hypoxia linked to renal injury by CCAAT/enhancer-binding protein delta. Kidney Int 88:262-275

37. Kalogeris T, Baines CP, Krenz M, Korthuis RJ (2012) Cell biology of Ischaemia/reperfusion injury. Int Rev Cell Mol Biol 298: 229-317

38. Sutton TA (2009) Alteration of microvascular permeability in acute kidney injury. Microvasc Res 77:4-7

39. Verma SK, Molitoris BA (2015) Renal endothelial injury and microvascular dysfunction in acute kidney injury. Semin Nephrol 35:96-107

40. Kumar P, Shen Q, Pivetti CD, Lee ES, Wu MH, Yuan SY (2009) Molecular mechanisms of endothelial hyperpermeability: implications in inflammation. Expert Rev Mol Med 11:e19-e19

41. Bonventre JV, Yang L (2011) Cellular pathophysiology of ischaemic acute kidney injury. J Clin Invest 121:4210-4221

42. Basile DP, Donohoe D, Roethe K, Osborn JL (2001) Renal ischemic injury results in permanent damage to peritubular capillaries and influences long-term function. Am J Physiol Renal Physiol 281:F887

43. Steegh FMEG, Gelens MACJ, Nieman FHM, van Hooff JP, Cleutjens JPM, van Suylen RJ, Daemen MJAP, van Heurn ELW, Christiaans MHL, Peutz-Kootstra CJ (2011) Early loss of peritubular capillaries after kidney transplantation. J Am Soc Nephrol 22:1024-1029

44. Basile DP, Yoder MC (2014) Renal endothelial dysfunction in acute kidney ischemia reperfusion injury. Cardiovasc Hematol Disord Drug Targets 14:3-14

45. Basile DP, Donohoe DL, Roethe K, Mattson DL (2003) Chronic renal hypoxia after acute ischemic injury: effects of L-arginine on hypoxia and secondary damage. Am J Physiol Renal Physiol 284: F338

46. Spurgeon-Pechman KR, Donohoe DL, Mattson DL, Lund H, James L, Basile DP (2007) Recovery from acute renal failure predisposes hypertension and secondary renal disease in response to elevated sodium. Am J Physiol Renal Physiol 293:F269-F278

47. Basile DP, Friedrich JL, Spahic J, Knipe N, Mang H, Leonard EC, Changizi-Ashtiyani S, Bacallao RL, Molitoris BA, Sutton TA (2011) Impaired endothelial proliferation and mesenchymal transition contribute to vascular rarefaction following acute kidney injury. Am J Physiol Renal Physiol 300:F721-F733

48. Basile DP (2007) The endothelial cell in ischemic acute kidney injury: implications for acute and chronic function. Kidney Int 72: $151-156$

49. Dragun D, Hoff U, Park JK, Qun Y, Schneider W, Luft FC, Haller H (2001) Prolonged cold preservation augments vascular injury independent of renal transplant immunogenicity and function. Kidney Int 60:1173-1181 
50. Neto JS, Nakao A, Kimizuka K, Romanosky AJ, Stolz DB, Uchiyama T, Nalesnik MA, Otterbein LE, Murase N (2004) Protection of transplant-induced renal ischemia-reperfusion injury with carbon monoxide. Am J Physiol Renal Physiol 287:F979

51. Kosieradzki M, Rowinski W (2008) Ischemia/reperfusion injury in kidney transplantation: mechanism and prevention. Transplant Proc 40:3279-3288

52. Kolaczkowska E, Kubes P (2013) Neutrophil recruitment and function in health and inflammation. Nat Rev Immunol 13:159 175

53. Chaturvedi S, Yuen DA, Bajwa A, Huang YW, Sokollik C, Huang L, Lam GY, Tole S, Liu GY, Pan J, Chan L, Sokolskyy Y, Puthia M, Godaly G, John R, Wang C, Lee WL, Brumell JH, Okusa MD, Robinson LA (2013) Slit2 prevents neutrophil recruitment and renal ischemia-reperfusion injury. J Am Soc Nephrol 24:12741287

54. Kinsey GR, Li L, Okusa MD (2008) Inflammation in acute kidney injury. Nephron Exp Nephrol 109:e102-e107

55. Thornton MA, Winn R, Alpers CE, Zager RA (1989) An evaluation of the neutrophil as a mediator of in vivo renal ischemicreperfusion injury. Am J Pathol 135:509-515

56. Yago T, Petrich BG, Zhang N, Liu Z, Shao B, Ginsberg MH, McEver RP (2015) Blocking neutrophil integrin activation prevents ischemia-reperfusion injury. J Exp Med 212:1267

57. Kelly KJ, Williams WW, Colvin RB, Meehan SM, Springer TA, Gutierrez-Ramos JC, Bonventre JV (1996) Intercellular adhesion molecule-1-deficient mice are protected against ischemic renal injury. J Clin Invest 97:1056-1063

58. Haug CE, Colvin RB, Delmonico FL, Auchincloss H Jr, TolkoffRubin N, Preffer FI, Rothlein R, Norris S, Scharschmidt L, Cosimi AB (1993) A phase I trial of immunosuppression with anti-ICAM1 (CD54) $\mathrm{mAb}$ in renal allograft recipients. Transplantation 55: 766-772

59. Melnikov VY, Faubel S, Siegmund B, Lucia MS, Ljubanovic D, Edelstein CL (2002) Neutrophil-independent mechanisms of caspase-1- and IL-18-mediated ischemic acute tubular necrosis in mice. J Clin Invest 110:1083-1091

60. Salmela K, Wramner L, Ekberg H, Hauser I, Bentdal O, Lins LE, Isoniemi H, Backman L, Persson N, Neumayer HH, Jorgensen PF, Spieker C, Hendry B, Nicholls A, Kirste G, Hasche G (1999) A randomized multicenter trial of the anti-ICAM-1 monoclonal antibody (enlimomab) for the prevention of acute rejection and delayed onset of graft function in cadaveric renal transplantation: a report of the European anti-ICAM-1 renal transplant study group. Transplantation 67:729-736

61. Friedewald JJ, Rabb H (2004) Inflammatory cells in ischemic acute renal failure. Kidney Int 66:486-491

62. Lu L, Faubel S, He Z, Andres Hernando A, Jani A, Kedl R, Edelstein CL (2012) Depletion of macrophages and dendritic cells in ischemic acute kidney injury. Am J Nephrol 35:181-190

63. Jo SK, Sung SA, Cho WY, Go KJ, Kim HK (2006) Macrophages contribute to the initiation of ischaemic acute renal failure in rats. Nephrol Dial Transplant 21:1231-1239

64. Huen SC, Cantley LG (2015) Macrophage-mediated injury and repair after ischemic kidney injury. Pediatr Nephrol 30:199-209

65. Huen SC, Cantley LG (2017) Macrophages in renal injury and repair. Annu Rev Physiol 79:449-469

66. Jose MD, Le Meur Y, Atkins RC, Chadban SJ (2003) Blockade of macrophage colony-stimulating factor reduces macrophage proliferation and accumulation in renal allograft rejection. Am J Transplant 3:294-300

67. Sheerin NS, Risley P, Abe K, Tang Z, Wong W, Lin T, Sacks SH (2008) Synthesis of complement protein C3 in the kidney is an important mediator of local tissue injury. FASEB J 22:1065-1072
68. Brar JE, Quigg RJ (2014) Complement activation in the tubulointerstitium: AKI, CKD, and in between. Kidney Int 86 : 663-666

69. Fearn A, Sheerin NS (2015) Complement activation in progressive renal disease. World J Nephrol 4:31-40

70. Cernoch M, Viklicky O (2017) Complement in kidney transplantation. Front Med 4:1-11

71. Abe K, Li K, Sacks SH, Sheerin NS (2004) The membrane attack complex, C5b-9, up regulates collagen gene expression in renal tubular epithelial cells. Clin Exp Immunol 136:60-66

72. Farrar CA, Tran D, Li K, Wu W, Peng Q, Schwaeble W, Zhou W, Sacks SH (2016) Collectin-11 detects stress-induced L-fucose pattern to trigger renal epithelial injury. J Clin Invest 126:1911-1925

73. Lee HT, Kim M, Kim M, Kim N, Billings FT 4th, D'Agati VD, Emala CW Sr (2007) Isoflurane protects against renal ischemia and reperfusion injury and modulates leukocyte infiltration in mice. Am J Physiol Renal Physiol 293:F713-F722

74. Zhang ZX, Wang S, Huang X, Min WP, Sun H, Liu W, Garcia B, Jevnikar AM (2008) NK cells induce apoptosis in tubular epithelial cells and contribute to renal ischemia-reperfusion injury. J Immunol 181:7489-7498

75. Li L, Huang L, Sung SS, Lobo PI, Brown MG, Gregg RK, Engelhard VH, Okusa MD (2007) NKT cell activation mediates neutrophil IFN-gamma production and renal ischemia-reperfusion injury. J Immunol 178:5899-5911

76. Dong X, Swaminathan S, Bachman LA, Croatt AJ, Nath KA, Griffin MD (2007) Resident dendritic cells are the predominant TNF-secreting cell in early renal ischemia-reperfusion injury. Kidney Int 71:619-628

77. Loverre A, Capobianco C, Stallone G, Infante B, Schena A, Ditonno P, Palazzo S, Battaglia M, Crovace A, Castellano G, Ranieri E, Schena FP, Gesualdo L, Grandaliano G (2007) Ischemia-reperfusion injury-induced abnormal dendritic cell traffic in the transplanted kidney with delayed graft function. Kidney Int 72:994-1003

78. Rabb H, Daniels F, O'Donnell M, Haq M, Saba SR, Keane W, Tang WW (2000) Pathophysiological role of T lymphocytes in renal ischemia-reperfusion injury in mice. Am J Physiol Renal Physiol 279:F525-F531

79. Burne MJ, Daniels F, El Ghandour A, Mauiyyedi S, Colvin RB, O'Donnell MP, Rabb H (2001) Identification of the CD4(+) T cell as a major pathogenic factor in ischemic acute renal failure. $\mathrm{J} C$ lin Invest 108:1283-1290

80. Savransky V, Molls RR, Burne-Taney M, Chien CC, Racusen L, Rabb H (2006) Role of the T-cell receptor in kidney ischemiareperfusion injury. Kidney Int 69:233-238

81. Monteiro RM, Camara NO, Rodrigues MM, Tzelepis F, Damiao MJ, Cenedeze MA, Teixeira Vde P, dos Reis MA, Pacheco-Silva A (2009) A role for regulatory $T$ cells in renal acute kidney injury. Transpl Immunol 21:50-55

82. Kinsey GR, Okusa MD (2014) Expanding role of T cells in acute kidney injury. Curr Opin Nephrol Hypertens 23:9-16

83. Linfert D, Chowdhry T, Rabb H (2009) Lymphocytes and ischemia-reperfusion injury. Transplant Rev 23:1-10

84. Burne-Taney MJ, Ascon DB, Daniels F, Racusen L, Baldwin W, Rabb H (2003) B cell deficiency confers protection from renal ischemia reperfusion injury. J Immunol 171:3210-3215

85. Jang HR, Gandolfo MT, Ko GJ, Satpute SR, Racusen L, Rabb H (2010) B cells limit repair after ischemic acute kidney injury. J Am Soc Nephrol 21:654-665

86. Renner B, Strassheim D, Amura CR, Kulik L, Ljubanovic D, Glogowska MJ, Takahashi K, Carroll MC, Holers VM, Thurman JM (2010) B cell subsets contribute to both renal injury and renal protection after ischemia/reperfusion. J Immunol 185: $4393-4400$ 
87. Takaori K, Nakamura J, Yamamoto S, Nakata H, Sato Y, Takase M, Nameta M, Yamamoto T, Economides AN, Kohno K, Haga H, Sharma K, Yanagita M (2016) Severity and frequency of proximal tubule injury determines renal prognosis. J Am Soc Nephrol 27: 2393-2406

88. Heyman SN, Rosenberger C, Rosen S (2010) Experimental ischemia-reperfusion: biases and myths - the proximal vs. distal hypoxic tubular injury debate revisited. Kidney Int 77:9-16

89. Sutton TA, Molitoris BA (1998) Mechanisms of cellular injury in ischemic acute renal failure. Semin Nephrol 18:490-497

90. Kapper S, Beck G, Riedel S, Prem K, Haak M, van der Woude FJ, Yard BA (2002) Modulation of chemokine production and expression of adhesion molecules in renal tubular epithelial and endothelial cells by catecholamines. Transplantation 74:253-260

91. Moll S, Ebeling M, Weibel F, Farina A, Rosario AAD, Hoflack JC, Pomposiello S, Prunotto M (2013) Epithelial cells as active player in fibrosis: findings from an in vitro model. PLoS One 8: e56575

92. Leemans JC, Stokman G, Claessen N, Rouschop KM, Teske GJD, Kirschning CJ, Akira S, van der Poll T, Weening JJ, Florquin S (2005) Renal-associated TLR2 mediates ischemia/reperfusion injury in the kidney. J Clin Invest 115:2894-2903

93. Wu H, Chen G, Wyburn KR, Yin J, Bertolino P, Eris JM, Alexander SI, Sharland AF, Chadban SJ (2007) TLR4 activation mediates kidney ischemia/reperfusion injury. J Clin Invest 117: 2847-2859

94. Pulskens WP, Teske GJ, Butter LM, Roelofs JJ, van der Poll T, Florquin S, Leemans JC (2008) Toll-like receptor-4 coordinates the innate immune response of the kidney to renal ischemia/ reperfusion injury. PLoS One 3:e3596

95. Lan R, Geng H, Polichnowski AJ, Singha PK, Saikumar P, McEwen DG, Griffin KA, Koesters R, Weinberg JM, Bidani AK, Kriz W, Venkatachalam MA (2012) PTEN loss defines a TGF-beta-induced tubule phenotype of failed differentiation and JNK signaling during renal fibrosis. Am J Physiol Renal Physiol 302:F1210-F1223

96. Venkatachalam MA, Weinberg JM, Kriz W, Bidani AK (2015) Failed tubule recovery, AKI-CKD transition, and kidney disease progression. J Am Soc Nephrol 26:1765-1776

97. Bonventre JV (2010) Pathophysiology of AKI: injury and normal and abnormal repair. Contrib Nephrol 165:9-17

98. Yang L, Besschetnova TY, Brooks CR, Shah JV, Bonventre JV (2010) Epithelial cell cycle arrest in G2/M mediates kidney fibrosis after injury. Nat Med 16:535-543

99. Suzuki T, Kimura M, Asano M, Fujigaki Y, Hishida A (2001) Role of atrophic tubules in development of interstitial fibrosis in microembolism-induced renal failure in rat. Am J Pathol 158:75-85

100. Canaud G, Bonventre JV (2015) Cell cycle arrest and the evolution of chronic kidney disease from acute kidney injury. Nephrol Dial Transplant 30:575-583

101. Kashani K, Al-Khafaji A, Ardiles T, Artigas A, Bagshaw SM, Bell M, Bihorac A, Birkhahn R, Cely CM, Chawla LS, Davison DL,
Feldkamp T, Forni LG, Gong MN, Gunnerson KJ, Haase M, Hackett J, Honore PM, Hoste EA, Joannes-Boyau O, Joannidis M, Kim P, Koyner JL, Laskowitz DT, Lissauer ME, Marx G, McCullough PA, Mullaney S, Ostermann M, Rimmele T, Shapiro NI, Shaw AD, Shi J, Sprague AM, Vincent JL, Vinsonneau C, Wagner L, Walker MG, Wilkerson RG, Zacharowski K, Kellum JA (2013) Discovery and validation of cell cycle arrest biomarkers in human acute kidney injury. Crit Care 17:R25

102. Maarouf OH, Aravamudhan A, Rangarajan D, Kusaba T, Zhang V, Welborn J, Gauvin D, Hou X, Kramann R, Humphreys BD (2016) Paracrine Wnt1 drives interstitial fibrosis without inflammation by tubulointerstitial cross-talk. J Am Soc Nephrol 27:781790

103. Nangaku M, Hirakawa Y, Mimura I, Inagi R, Tanaka T (2017) Epigenetic changes in the acute kidney injury-to-chronic kidney disease transition. Nephron 137:256-269

104. Rodriguez-Romo R, Berman N, Gomez A, Bobadilla NA (2015) Epigenetic regulation in the acute kidney injury (AKI) to chronic kidney disease transition (CKD). Nephrology (Carlton) 20:736743

105. Mimura I, Tanaka T, Nangaku M (2016) New insights into molecular mechanisms of epigenetic regulation in kidney disease. Clin Exp Pharm Physiol 43:1159-1167

106. Bechtel W, McGoohan S, Zeisberg EM, Muller GA, Kalbacher H, Salant DJ, Muller CA, Kalluri R, Zeisberg M (2010) Methylation determines fibroblast activation and fibrogenesis in the kidney. Nat Med 16:544-550

107. Liu N, He S, Ma L, Ponnusamy M, Tang J, Tolbert E, Bayliss G, Zhao TC, Yan H, Zhuang S (2013) Blocking the class I histone deacetylase ameliorates renal fibrosis and inhibits renal fibroblast activation via modulating TGF-Beta and EGFR signaling. PLoS One 8:e54001

108. Wing MR, Ramezani A, Gill HS, Devaney JM, Raj DS (2013) Epigenetics of progression of chronic kidney disease: fact or fantasy? Semin Nephrol 33:363-374

109. Wynn TA (2010) Fibrosis under arrest. Nat Med 16:523-525

110. McDonald OG, Wu H, Timp W, Doi A, Feinberg AP (2011) Genome-scale epigenetic reprogramming during epithelial-tomesenchymal transition. Nat Struct Mol Biol 18:867-874

111. Li Y-F, Jing Y, Hao J, Frankfort NC, Zhou X, Shen B, Liu X, Wang L, Li R (2013) MicroRNA-21 in the pathogenesis of acute kidney injury. Protein Cell 4:813-819

112. van den Akker EK, Dor FJ, IJzermans JN, de Bruin RW (2015) MicroRNAs in kidney transplantation: living up to their expectations? J Transp Secur 2015:354826

113. Aguado-Fraile E, Ramos E, Sáenz-Morales D, Conde E, BlancoSánchez I, Stamatakis K, Peso LD, Cuppen E, Brune B, Laura M, Bermejo G (2012) miR-127 protects proximal tubule cells against ischemia/reperfusion: identification of kinesin family member 3B as miR-127 target. PLoS One 7:e44305 